\title{
The Economic and Legal Analysis of the Terms of International Delivery Contracts Involving Russian Suppliers
}

Submitted 17/01/20, $1^{\text {st }}$ revision 21/01/20, $2^{\text {nd }}$ revision 20/02/20, accepted 05/03/20

\author{
T.A. Skvortsova ${ }^{1}$, G.S. Pratsko ${ }^{2}$, Yu.I. Isakova ${ }^{3}$, \\ E.V. Seregina ${ }^{4}$, V.N. Sevumyan ${ }^{5}$
}

\begin{abstract}
:
Purpose: The article presents an economic and legal analysis of the terms of contracts for international delivery of goods involving Russian suppliers.

Design/Methodology/Approach: The authors analysed the international norms of regulating relations for the goods' delivery involving the foreign element. Terms of the goods delivery are investigated according to the national legislation of the Russian Federation.

Findings: As a result, it is necessary to use an economic and legal approach when developing contract terms for the goods' delivery to take into account norms of international law, the national legislation of the supplier country and in accordance with the calculations of the contract price and payment terms.

Practical Implications: The proposed method is in accordance with the international legal framework and it can be adopted by the Russian Federation easily.

Originality/Value: There is no such an approach eligible to modernize the existing system in the country.
\end{abstract}

Keywords: Business activity, international delivery of goods, contract of international sale of goods, supplier, buyer, terms of the delivery contract.

JEL Classification Codes: F10, K12, C00.

Article Type: Research study.

\footnotetext{
${ }^{1}$ Associate Professor, Ph.D. in Law, Rostov State University of Economics, Rostov State

Transport University, Rostov-on-Don, Russian Federation, tas242@yandex.ru

${ }^{2}$ Professor, Doctor in Law, Don State Technical University, Rostov State Transport

University, Rostov-on-Don, Russian Federation, gpip@ rgups.ru

${ }^{3}$ Professor, Doctor in Sociology, Ph.D. in Law, Don State Technical University, Rostov-on-

Don, Russian Federation, isakova.pravo@bk.ru

${ }^{4}$ Associate Professor, Ph.D. in Law, Russian State University of Justice, Rostov-on-Don,

Russian Federation, seregina51@mail.ru

${ }^{5}$ Associate Professor, Ph.D. in Law, Rostov State University of Economics, Rostov-on-Don,

Russian Federation, sevar_@mail.ru
} 


\section{Introduction}

In the market economy, the institution of goods delivery is very important. Today, in conditions of contract relations, the delivery contract is the main legal form of relations between industry and trade. Delivery also plays an important role in international trade. The delivery contract is one of the most frequently used contracts in the international economic turnover. The large number of international agreements in the commercial turnover, the complex process of forming, developing and unifying such agreements by most countries, the inability of the state mechanism to adequately and quickly respond to the needs of the commercial market, to develop the necessary legal solutions present the lack of effectiveness of the existing international legal system in commercial relations. All this indicates the search for the necessary alternative ways of legal regulation of relations between entrepreneurs (Shatkovskaya and Epifanova, 2016). First of all, this concerns the development of adequate conditions for contractual relations.

This raises the question of the need for the specific practical recommendations to conclude delivery contract, for which it is advisable to make an economic and legal analysis of the contractual relations of delivery in international trade.

\section{International Rules Regulating Relations for the Goods' Delivery Involving a Foreign Element}

The most important universal international legal act in international commercial relations is the UN Convention on contracts for the international sale of goods, developed within the UN Commission on international trade law and adopted at the UN international conference held in Vienna (March 10 - April 11, 1980, hereinafter the Vienna Convention). The adoption of the Vienna Convention in 1980 was preceded by the development and adoption of two Hague sales conventions in 1964 the Convention on the Uniform law on the international sale of goods and the Convention on the Uniform law on the conclusion of international sales contracts.

The conventions were not widely applied because they considered mainly the legal traditions and economic realities of the continental countries of Western Europe, that is, the region that took the most active part in their preparation.

In order to maximize the number of participants in the 1980 Vienna Convention and make it a universal document, the authors of the Convention tried to consider the interests of existing national legal systems, primarily continental and AngloAmerican ones. As a result, the Convention reflects the characteristics of these two legal systems. Due to this fact, the number of the Convention participants is more than 70 states and tends to grow (Kanashevsky, 2008). The success in creating Uniform international conflict-of-laws rules is obvious, but they have not completely eliminated the need to use national law yet. Directly in the text of the Vienna Convention, only some of unresolved in its issues are identified. According to article 
4 of the Convention, since it does not provide otherwise, it does not concern, in particular, the validity of the contract, or any of its provisions, or any custom; the effects that the contract may have on the ownership of the sold goods. However, according to the practice of dispute resolution it is necessary to solve other important international contracts of sale, subordinated to the Convention, but not received uniform regulation (for example, collecting of the contractual penalty, reducing its size, the ratio of losses, the size of annual interest rates and their calculation procedure for delay of a monetary obligation, limitation period issues).

The procedure for resolving these unresolved issues is defined in article 7, paragraph 2 of the Convention, according to which issues related to the subject matter of its regulation, but explicitly not resolved in it, are to be resolved in accordance with the general principles on which it is based, and if there are no such principles, these issues are to be resolved in accordance with the law applicable by the rules of private international law.

The Vienna Convention applies to contracts for the sale of goods between parties, enterprises of which are located in different states, when these states are contracting parties or when, according to a conflict of laws rule, the law of the state - the party to the Convention - is considered to be the national law applicable to the contract even if the place of business of one or both parties is not located in states -parties to the Convention.

The term "commercial enterprise of the party" describes not the subject of law, but the place of the main activity of the party, the permanent place of business operations (place of business). Thus, the nationality (state affiliation) of a party does not matter to the decision on the Convention applicability.

At the same time, referring to foreign publications Zykin in the commentary to the Vienna Convention of 1980 notes that "a commercial enterprise may be the location of the main office of a legal entity, as well as its representative office or branch". If the place of the agent activity, representative office, branch of the seller or buyer is closely related to the contract of sale and its execution, they should be considered to be a commercial enterprise for the purposes of paragraph 1 of article 1 of the Convention" (Boguslavsky, Vilkova, Gorodissky, Zykin, 1994). This approach is rather defective. The branch and representative office are the structural subdivisions of the legal entity, and therefore cannot enter into transactions on their own behalf, and all the contracts concluded by them are considered to be concluded by the legal entity itself.

The nationality (state affiliation) of the party does not matter to the decision on the applicability of the Convention (article 1, paragraph 3). Thus, if the commercial enterprises of the parties are located in the same state, the Convention is not applied, even in spite of different nationalities of the parties (Kanashevskv, 2008). 
However, it should be admitted that, first, the Vienna Convention is based on the principle of autonomy of the parties' will, which means that the parties can exclude its application to legal relations in whole, or deviate from any of its provisions or change their effect (article 6 of the Convention).

In other words, the terms of a specific international sales contract have priority over the Vienna Convention. Second, in cases where the issue under the Vienna Convention is not explicitly resolved and cannot be resolved in accordance with its general principles, the applicable law is determined by the rules of private international law (conflict of laws).

Thus, in certain cases, Russian civil law both as the main law and as the additional (subsidiary) one is applicable to relations arising from the international sales contract and falling within the scope of the Vienna Convention. Determining the sphere of the Vienna Convention application, it is necessary to consider the limitations of the subject matter of the Convention itself.

Some issues related to the conclusion and execution of the international sales contract are not regulated by the Vienna Convention at all, and some provisions relating to sales contracts contained in Russian legislation differ from those of the Vienna Convention. In the first case, Russian legislation is subject to subsidiary application; in the second case, the provisions of the Vienna Convention apply.

Thus, Russian national legislation plays an important role in regulating contractual relations for the international delivery of goods involving Russian suppliers.

\section{National Rules of Russian Law Regulating the Terms of Delivery Contracts, the Development of Contract Terms}

Article 506 of the Civil code of the Russian Federation determines that according to such a contract supplier-seller carrying out entrepreneurial activity, undertakes to transfer in the caused term or terms produced or purchased goods to the buyer for the use in the entrepreneurial activity or for other purposes unrelated to the personal, family, home and other similar use.

It should be noted that the subject of the delivery contract can be any items that are not withdrawn from circulation (individually defined and defined by generic characteristics). This excludes the so-called delivery of property rights, security papers, and shares in the authorized capital of business entities. Results of the intellectual activity cannot be transferred under such an agreement (Shatkovskaya, Solonchenko, Emirsultanov and Naumenko, 2017).

In the special literature, the point of view was expressed, according to which, only new things not used before can be the subject of delivery (Klein, 1997). In our 
opinion, the degree of "deterioration" (not novelty) of things does not matter, because things used before, such as car tires can be the subject of delivery.

Features in the legal regulation of delivery relations are clearly expressed at the stage of concluding the contract. The Civil code (article 507) provides a special procedure of pre-contractual relationships of parties interested in the contract.

The delivery contract is consensual because it is considered to be concluded from the moment when the parties have reached an agreement on all the significant terms. The significant term of this agreement in accordance with articles 432, 506 of the Civil code is the subject of the contract and delivery time.

Meanwhile, the question about whether the delivery time of the goods is significant is debatable. Some civilists consider the time of the goods delivery not to be a significant term of the delivery contract. Thus, Klein writes "there is no rule in the Civil code ... considering the term of goods transfer to be significant terms of the contract of sale or delivery, so there is no reason to consider the time of delivery to be significant, although article 506 of the Civil code contains the indication of the time" (Klein, 1997).

The judicial practice tradition is based on section 7 of the Resolution of Plenum of the Supreme arbitration court of the Russian Federation from 22.10.1997 No 18 "About some questions connected with application of the provisions of the Civil code of the Russian Federation on the delivery contract" according to which this term is significant, but measurable. It seems that the entrepreneurial nature of the delivery relationship requires to determine the delivery time more definitely. This is necessary for both the supplier and the buyer.

The need to agree on the delivery time as an essential term of the contract is substantiated by the business specifics of the delivery relationship. Therefore, we consider the opinion of Filatova (2010) to be fair, according to which it is necessary to add the Civil code of the Russian Federation with the Article 506.1. The terms of performance of the obligation to transfer the goods are:

1.The time of performance of the supplier's obligation to transfer the goods to the buyer is determined by the delivery contract.

2. The time of performance of the supplier's obligation to transfer the goods must be determined in accordance with the procedure provided by the Civil code of the Russian Federation.

3. The time specified in the delivery contract for performance of the supplier's obligation to deliver the goods to the buyer may be changed in the cases and in accordance with the procedure provided in the contract" (Filatova, 2010). 
In addition, in order to eliminate gaps and contradictions in law enforcement it is necessary to define the significant terms of the contract distinguishing it from other similar relationships. Some investigators propose to add the paragraph 2, article 506 of the Civil code with the words "the delivery contract is concluded, if it indicates the terms on the range, quantity, quality of goods" after the words...with the home and other similar use".

The price is an important term of the delivery contract. The buyer under the delivery contract is obliged to pay that price for the goods which is stipulated in the delivery contract, or that price which is usual for a similar product sold under comparable circumstances.

The price is not important, except those cases when the parties consider it to be important. Although sometimes courts still consider this term to be important. For example, the decision of the FAS of the East Siberian district from June 17, 2010 in case No A33-19961/2009.

In practice, the payment for goods is the point of the delivery contract arising multiple disputes. The contract may specify one of the payment options for the product:

- pre-payment;

- post-payment or payment "in fact";

- combination: the part is prepayment, the part is post-pay;

- deferred payment.

Let us make an economic analysis of the delivery contract with the deferred payment for 2 months and the $40 \%$ prepayment in the amount of 200,000 rubles. The contract time is January 1, 2019 - February, 28, 2019.

To determine the prepayment amount and calculate the amount of subsequent payments, it is necessary to make calculations using formulas. The prepayment amount is determined:

$\mathrm{P}=\mathrm{D} * 40 \%$,

Where:

D - amount of the delivery contract;

$40 \%$ - the prepayment percentage.

Let us make a calculation:

$20000 * 40 \%=80000$ rubles. 
Therefore, 80000 rubles is the amount that the buyer pays as the prepayment.

- the remaining payment amount is determined by the formula:

$\mathrm{O}=\mathrm{D}-\mathrm{P}$

$\mathrm{R}=200000-80000=120000$ rubles

The calculation shows that 120,000 rubles is the amount of subsequent payments that must be made within two months. Since payments must be made in equal instalments (according to the agreement), and there are two such payments (according to the number of months of instalments), it is necessary to determine the amount of each subsequent payment. The amount of each subsequent payment is determined by the formula:

$\mathrm{Pp}=\mathrm{R} / 2$,

where

$\mathrm{R}$ - the remaining amount of the payment;

2 - the number of instalment payment months.

After making the calculation, we get:

$\mathrm{Pp}=120000 / 2=60000$ rubles

The calculation presents that 60,000 rubles is the amount that must be paid as the deferred payment amount before the term specified in the contract during two payment periods.

Since the contract must specify not only the amount of the subsequent payment, but also its percentage of the total purchase amount, it is advisable to determine the percentage by the formula.

- the amount of the subsequent payment as a percentage is determined by the formula;

- the amount of the subsequent payment as a percentage is determined by the formula.

$\mathrm{R} \%=100 \%-40 \%$,

where

$100 \%$ - the amount of the delivery contract as a percentage;

$40 \%$ - the prepayment amount as a percentage. 
After making the calculation, we get:

$100 \%-40 \%=60 \%$ - the amount of the subsequent payment as a percentage.

Thus, the contract clause "time and terms of delivery and payment" of the delivery contract is added with the following entry, all amounts of which (both in real measurement and as a percentage) are confirmed by mathematical calculations: "The buyer takes the goods with deferred payment for 2 months, makes $40 \%$ payment 80,000 rubles (eighty thousand) of the total contract of 200,000 rubles (two hundred thousand), and the buyer pays the remaining 60\% - 120,000 rubles (one hundred and twenty thousand rubles) from the date of shipment of the goods from the supplier's warehouse in equal installments until February, 1, 2019, 60,000 rubles (sixty thousand) and up to March, 1, 2019-60,000 rubles (sixty thousand)".

The contract payment is not the only important point of the delivery contract. In addition, it is necessary to pay attention and make an economic substantiation for its significant items such as the payment form, the time of payment, the unit of account, etc., (Nesterova and Skvortsova, 2019).

\section{Conclusion}

Thus, relations on international deliveries of goods are regulated primarily by international agreements, among which the UN Vienna Convention on contracts for the international sale of goods plays is especially important. But this Convention regulates only a narrow range of relations. In this regard, when concluding contracts with a Russian supplier, many issues of delivery will be regulated by the national legislation of Russia (the conflict of laws binding is applicable - the law of the supplier's country).

In order to avoid economic risks, we would recommend making the following actions before entering the delivery contract:

- to carefully analyse the proposed contract;

- to identify property, financial, and tax risks arising from the contract or its draft;

- to determine which conditions in the draft contract should be deleted, changed or added;

- to develop a reasoned position in negotiations with the other party on the conclusion of the proposed version of the delivery contract.

\section{References:}

Boguslavsky, M.M., Vilkova, N.G., Gorodissky, A.M., Zykin, I.S. 1994.

Vienna Convention on Contracts for the International Sale of Goods: Commentary.

Moscow, Legal literature.

Epifanova, T., Romanenko, N., Mosienko, T., Skvortsova, T., Kupchinskiy, A. 2015. 
Modernization of Institutional Environment of Entrepreneurship in Russia for Development of Innovation Initiative in Small Business Structures. European Research Studies Journal, 18(3), 137-148.

Filatova, M.A. 2010. Delivery Contract as a Type of Purchase and Sale Contract. Law and Politics, No. 9, 1679-1684.

Kanashevsky, V.A. 2008. Foreign Economic Transactions: Material and Legal Conflict Regulation. Moscow, Volters Kluver.

Klein, N.I. 1997. Delivery Contract. Legislation and Economics, No. 7-8, 37-54. United Nations Convention on Contracts for International Sale-sales of Goods, Vestnik SAC of the RF, No. 1.

Nesterova, N.V., Skvortsova, T.A. 2019. Economic and Legal Aspects of the Delivery Contracts in the Russian Federation. The Constitution of the Russian Federation as a Guarantor of Human and Civil Rights and Freedoms: Materials of the Second all-Russian National Scientific and Practical Conference. Rostov State University of Railways. Rostov n/D, 69-73.

Shatkovskaya, T.V., Epifanova, T.V. 2016. Correlation of private and public legal interests as theoretical and scientific and practical problems of modern law. Journal of Advanced Research in Law and Economics, 7(3), 625-643.

Shatkovskaya, T.V., Solonchenko, A.A., Emirsultanov, Ya.A., Naumenko, Yu.A. 2017. Leading Governments Legal Initiatives of Innovative Development in the Sphere of Commercialization of Intellectual Products. European Research Studies Journal, 20(3B), 432-442. 